\title{
13. Successful cases of Interactive Network Branding
}

\begin{abstract}
This chapter of the book focuses on presenting successful Interactive Network Branding (INB) illustrative case examples. We first present each case by tackling the specific issue that appears in each of the companies, after which we present possible solutions. These case examples serve two purposes. Firstly, they are illustrating contemporary issues that are relevant for small and medium-sized enterprises (SMEs), especially related to their fast growth on the market. As such, the cases are relevant for practitioners who are working in SMEs or having business relationships with them. Second, the study is relevant for students, especially at advanced levels of studies in business schools, who are interested in having their own company or working in an SME in the future. Besides, illustrative cases are often used to help readers comprehend "how the conceptual argument [in these cases INB] might actually be applied to one or more empirical settings"1.
\end{abstract}

Keywords: Interactive Network Branding; illustrative case examples; SMEs; practitioners; students; empirical settings.

\subsection{Case example 1: BonAlive}

In April 2016, the founder and Chief Executive Officer (CEO) of Bonalive, Dr. Fredrik Ollila, is wondering about the future of his company. Bonalive's business network is growing fast and Fredrik himself is visiting almost every customer personally. The firm is already having partners in 45 different countries, so the question that appears is: what will happen when the number of customers grows bigger than the number of days in a year? Will Fredrik be able to visit all customers and assist them in their needs?

\section{Background of the company}

Bonalive is a small company operating in the healthcare industry. It uses smart biomaterials with evidence-based technologies. The main goal of the Bonalive is to create "a smarter future for healthcare" ${ }^{2}$. The firm is a privately owned company with 30 employees, located in Turku, Finland. Bonalive is producing and selling CE-marked and 510k approved products made from bioactive glass for healing infected bones and other bone-related injuries. Their products are

\footnotetext{
${ }^{1}$ Siggelkow (2007, p. 22).

2 https://www.bonalive.com/company/ (accessed 24.06.2019)
} 
manufactured and sold for bone regeneration, promoting smart healing without the use of antibiotics.

In 2008, Dr. Ollila took responsibility for the Bonalive product-line at Vivoxid Oy. Soon after that, more precisely at the end of 2009, Dr. Ollila made an agreement with Vivoxid about buying-out Bonalive business, and the company Bonalive Biomaterials was founded.

During the first years, Dr. Ollila was focusing on building strong network connections, while at the same time, offering the best products and services to its customers:

"As the world seeks answers to the growing threat of antibiotic resistance, Smart Healing TM solutions represent a new standard in patient care. Evolving at the intersection of technology and human biology, our technologies reduce antibiotic treatments and enable a better quality of life for patients. It's time to heal smarter. "3

\section{Building business relationships}

By having revolutionary solutions for current problems of society and healthcare, Bonalive managed to internationalize right from the beginning, while building an extensive network of business relationships. However, it is important to note that Dr. Ollila, on behalf of Bonalive, chooses his partners very carefully. He does not focus on getting the cheapest resources; instead, he focuses on the best quality of resources and the potential for long-term partnerships. Simultaneously, Bonalive offers the best products and services and aims towards the high satisfaction of its buyers. And above all, they care about patients and what is best for them.

"Bonalive has experienced exponential growth throughout its history of serving patients, surgeons, and hospitals worldwide. Our expanding distribution network currently spans over 40 markets and we continuously seek new partners to join us in creating better patient outcomes.",

Figure 13.1. Business partners of Bonalive in orange (in 2016)

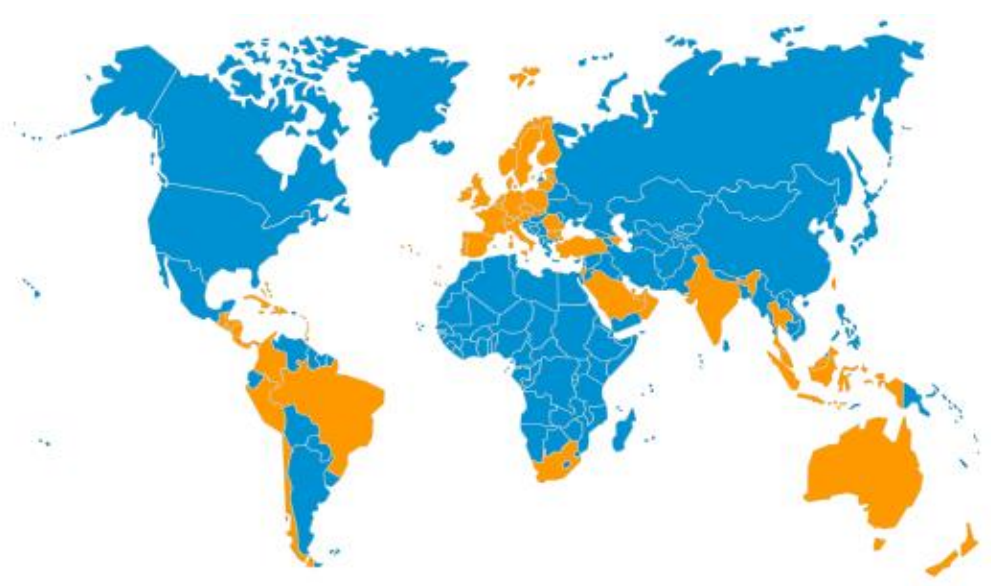

${ }^{3}$ https://www.bonalive.com/ (accessed 24.06.2019)

${ }^{4}$ https://www.bonalive.com/distribution/ (accessed 20.06.2019) 
Most of the business relationships are nowadays built through distributors that Bonalive has around the globe. Figure 2 represents the presence of Bonalive in the world in 2016. Some of those partnerships, although built through distributors, are often initiated by surgeons themselves, or even patients, who read about Bonalive products or came in contact with Dr. Ollila. Representatives of Bonalive, lead by Dr. Ollila, are also attending industry-specific conferences and congresses every year, in order to stay up to date with the current happenings in the industry, as well as to be close to their business partners. In addition to that, a lot of research publications are being conducted on the topic of Bonalive, focusing on diverse medical spheres. This has been a crucial aspect of Bonalive's success and growth, from the very beginning:

"A key aspect supporting our growth has been the extensive research made during some 20 years prior to starting in 2008. This research has ensured that the products perform as expected in a great variety of cases in a safe and dependable way." 5

An up-to-date list of more than 150 references can be received by contacting the company directly. Just as the CEO argues:

"We wanted to emphasize that one unique factor of Bonalive in the entire medical device industry is the availability of scientific references and studies made on our product. This lays the foundation for our commercialization and building of relationships and trust with partners and customers." 6

\section{The story of Bonalive's first products}

The products Bonalive is creating are based on smart healing of infected or injured bones, without the use of artificial products and antibiotics. This whole idea started quite a long time ago:

"In the late 1960s, an associate professor called Larry Hench traveled to an Army Materials Conference in Sagamore, New York, and seated himself next to a Vietnam veteran. Their discussions lead into the topic of bone recovery and methods of replacing the bone with a manmade material that the body would not reject. The 45S5 Hench glass was soon born. The glass had tissue regenerative properties and bonded tightly to the bone while being slowly biodegraded in the body.

A couple of decades after, in the 1980s, at the universities of Turku, Finland, the story of the Hench glass and its composition still puzzled scientists. What would happen if the composition were different, would it bring the same advantages or even new ones? Soon many different new bioactive glass compositions were developed and among them was the formula S53P4. As it turned out, as well as being strikingly osteostimulative (non-osteoinductive), S53P4 was found

\footnotetext{
${ }^{5}$ Interview with the CEO (in 2016)

${ }^{6}$ Interview with the CEO (in 2017)
} 
to have one new additional property that astounded its discoverers: the composition of 53\% silica and smaller weights of sodium, calcium, and phosphorus gave rise to surface reactions in vitro that appeared to be highly antibacterial by inhibiting bacterial growth - they had developed a material that could not be infected by bacteria."7

These materials and products, as shown in Picture 1, can be used in orthopedic, trauma, and cranio-maxillofacial surgeries, which results in saving costs and time of surgeries. The vision of Bonalive is: "to become the world-leader in providing synthetic biomaterial solutions for the treatment of chronically infected bone" and they are well on their way.

"We offer osteostimulative technologies that provide an extensive range of benefits for bone regeneration. Bonalive ${ }^{\circledR}$ granules and Bonalive ${ }^{\circledR}$ putty [see Picture 1] are highly effective technologies for the filling, reconstruction, and regeneration of bone defects. Bonalive ${ }^{\circledR}$ granules also have the unique feature of naturally inhibiting bacterial growth, making it a smarter and more sustainable solution for bone regeneration." 8

Picture 13.1. Bonalive ${ }^{\circledR}$ granules and Bonalive ${ }^{\circledR}$ putty
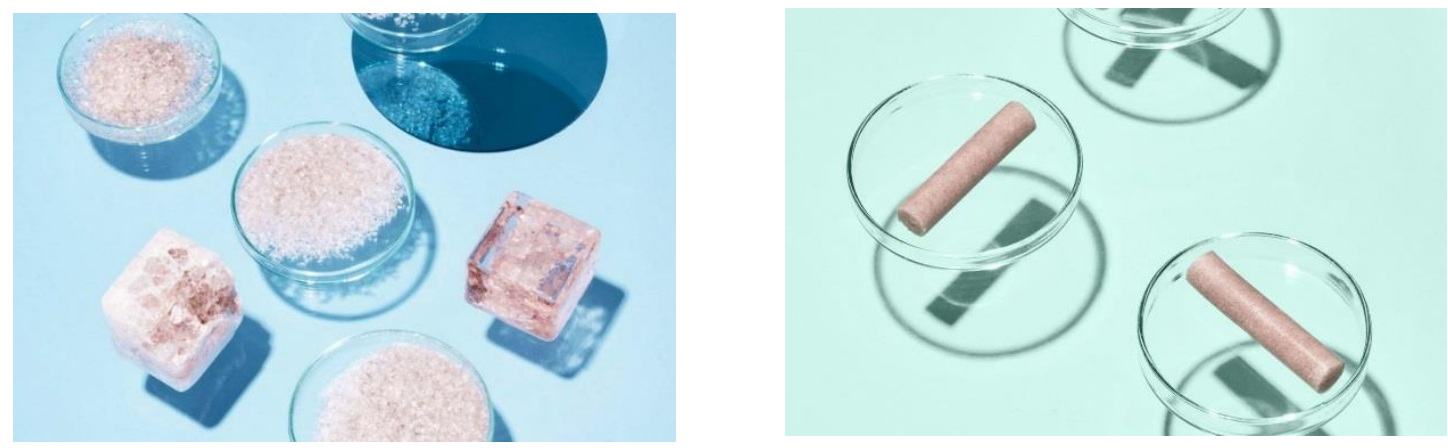

Source: https://www.bonalive.com/products/

"Today the story continues - the bioactive glass S53P4 is manufactured and provided worldwide by Bonalive Biomaterials Ltd in Turku Finland, the birth city of the technology. The products come in different package sizes and compositions. One of the Bonalive portfolio products, Bonalive ${ }^{\circledR}$ granules, is the only antibiotic-free biomaterial in the world with the claim to inhibit bacterial growth, with the official indication of bone cavity filling in the treatment of chronic osteomyelitis."

\section{Bonalive as a part of a bigger solution}

"Antibiotic resistance is estimated to have caused the death of over 700000 patients worldwide last year. In 2050, this number is forecast to rise to 10 million. As antibiotics are losing their effect at alarming speed new alternatives are being evaluated. According to a recent study, naturally antibacterial bioactive glass has shown excellent results for bone infections - without local antibiotics." 10 Thus, Bonalive is not only focused on satisfying its long-term business

\footnotetext{
${ }^{7}$ https://www.bonalive.com/our-story/ (accessed 19.06.2019)

8 https://www.bonalive.com/products/ (accessed 19.06.2019)

9 https://www.bonalive.com/our-story/ (accessed 19.06.2019)

${ }^{10} \mathrm{https} / / / \mathrm{www}$. businesswire.com/news/home/20170307005953/en/BonAlive-Biomaterials-Fighting-AntibioticResistance-Glass (accessed 24.06.2019)
} 
partners, but also on impacting the final users of their products, i.e., patients with serious injuries. In this manner, Bonalive is not only a profit-oriented firm, but a firm oriented to make the world a better and healthier place.

"At Bonalive Biomaterials we take great pride in our story and we want to share it with the world. At the core of our activity lies patient healing. We want to make a change through safe and high-quality innovations that take us beyond the reliability of antibiotics in bone infection surgery. The pain and devastation that chronically infected bone can render in a patient's daily life, affecting family, work and spare time, is what drives us forward to constantly develop new technologies and applications of our products. "11

\section{Interactive Network Branding as a way to go forward}

Throughout the first years of the firm's existence, the CEO played the leading role in representing the firm and promoting the products on its existing and potential markets. In most cases, Dr. Ollila was traveling alone, visiting hospitals and research centers, and most of the potential customers have contacted him personally. However, how the firm was growing, Dr. Ollila realized the need for involving more people, besides himself, in an acting role of the brand ambassador. He, thus, strategically broadened his team by dividing responsibilities among them in a way that everyone has a certain role in acting and interacting as a boundary spanner, with both current and potential business partners. On this way, the whole burden of representing the firm, initiating, and maintaining the relationships was not falling anymore on one person's shoulders, as was previously the case.

Dr. Ollila's team is working closely together in building a strong corporate identity, by growing as the high-tech, medical care, and knowledge leader in bone regeneration and antibacterial healing. Bonalive has skilled personnel with a scientific background, technological orientation, and a good cause in society, as the products are offering help to many people. This further reflects on the firm's reputation, i.e., on how Bonalive is recognized in the global market. As a result, the team is communicating the same brand message internally and externally, thus being able to convey the corporate brand on the market faster than the founder could alone. This is complemented with positive referrals from satisfied customers, publications in medical and other related journals, as well as successful surgeries, which furthermore provide strength to Bonalive's reputation on its domestic and international markets. For instance, leading surgeons in the field that use Bonalive's products can also act as a boundary spanners towards decision makers in hospitals, as well as among other surgeons, thus making products well known and the firm recognized on the market.

Although the future prospects for Bonalive look promising, what challenges lie ahead?

How will the world change and respond to antibiotic resistance in the future?

Will Bonalive become the world's leader in its field?

\footnotetext{
${ }^{11}$ https://www.bonalive.com/our-story/ (accessed 19.06.2019)
} 
Moreover, what role will firm representatives play in this development?

\subsection{Case example 2: MiTale}

In May 2019, the founder and Chief Executive Officer of MiTale, Natasha Bulatovic Trygg, is thinking about the right balance between the number of projects she should get engaged into, the number of employees she needs, and the optimal size of her company. The reason for this has been the increase of MiTale's recognition on the market, which resulted in more and more companies wanting to work with them. However, when the amount of work is growing exponentially, there

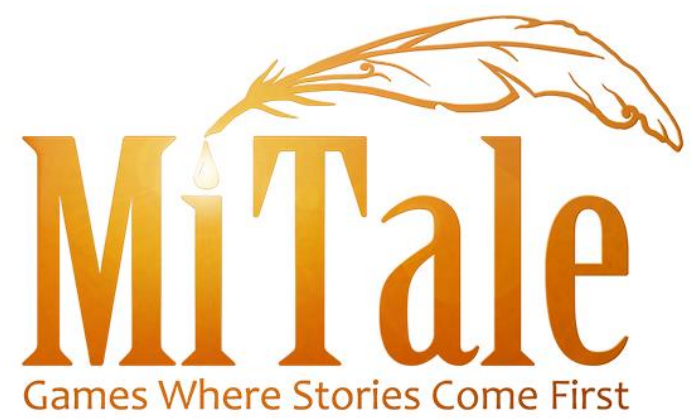
comes a need for certain changes in the company.

MiTale is a small company of 10 employees and Natasha would like it to stay that way. This small size allows them to pay enough attention to each business partner while solving problems of society, standing side by side. However, the problem appears when multiple potential partners are contacting them for a business collaboration, which spills over the capacities they currently have. What should Natasha do to keep MiTale small, but effective and positively recognized on the market?

\section{Background of the company}

MiTale Ltd. is a new SME company in the Finnish gaming industry. It has been established at the end of 2016 in Turku, Finland.

MiTale is focused on gamification and serious games. Their aim is to become experts in providing tailored interactive experiences for each individual user and their specific needs. Although the company sells its products to consumers as well, B2B services are the main factor that makes them independent on the market and allows them to gain profit.

MiTale currently has 10 employees, who are experienced professionals passionate about serious games and storytelling. The team is created from individuals who have been working in several different companies in the past. Throughout the years, these individuals have been collaborating on different projects, where they created mutual contacts and closer connection, which resulted in the creation of a new company.

Besides full-time employees, MiTale has five external experts who act as experts in various fields, starting from speech therapists, educational managers, professors, and business consultants. Over the years, the CEO has realized that having the right people involved in the right tasks is a crucial recipe for the success of every company, especially for an SME. 


\section{Products and services}

MiTale creates its products for both business-to-consumer (B2C) and business-to-business (B2B) markets. One of the latest products is "My First Calendar", which is "custom designed tool for families with children, especially those who attend speech therapy or need assistance in language learning". ${ }^{12}$

Picture 13.2. My First Calendar

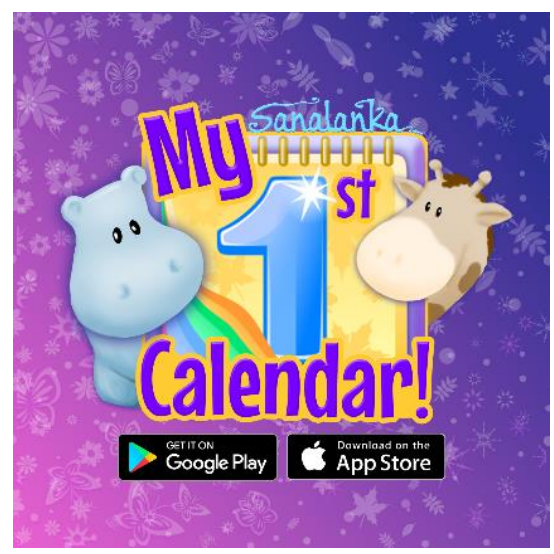

Sanalanka is another product of MiTale that is created for its B2B market. It is an Interactive Speech Therapy Environment presented as a book and sold as an application for mobile phones. "Sanalanka develops new services and effective solutions for children with speech development challenges by using gamification technologies."13

Picture 13.3. Sanalanka

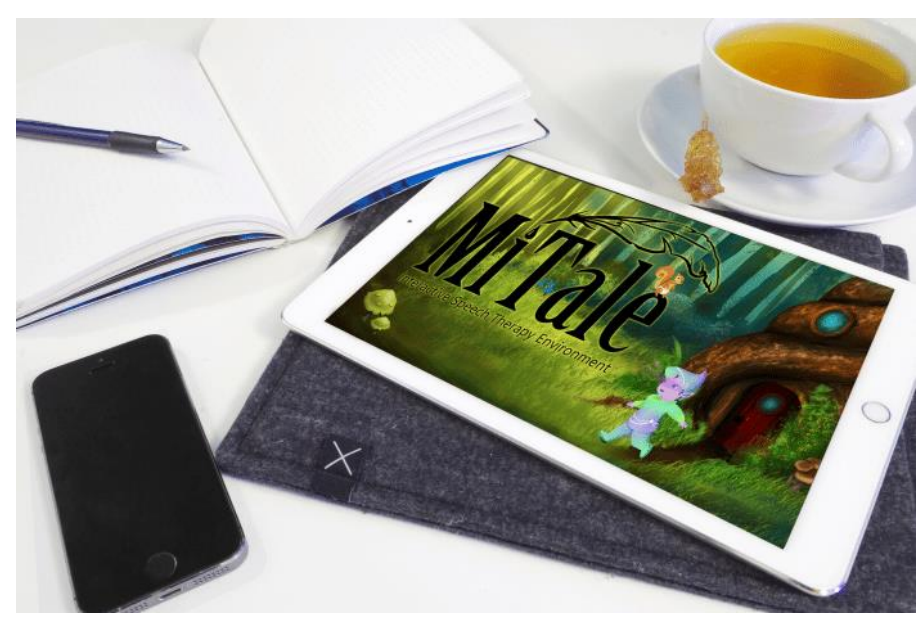

The first demo game of Sanalanka was created by Natasha and her old team members, already several years before MiTale was founded. Their aim with this product is the following:

"We provide a new medium for speech therapy, wellbeing, and language learning practices by fusing traditional methods together with the latest available technology such as speech recognition, neural networks and AI as well as its use in mixed reality.

\footnotetext{
${ }^{12} \mathrm{https://mitale.fi/} \mathrm{(accessed} \mathrm{25.06.2019)}$

${ }^{13}$ Ibid.
} 
Our solution is breaking the norms in treating communication boundaries that commonly lead to social exclusiveness. We make communicating easy, especially for those who need the assistance most." 14

In addition to above-mentioned products, MiTale also offers services for its business customers. Those include game development, gamification, consulting services, as well as gaming technology as a service, i.e., tailored gamification solutions for their clients, following the narrative:

"We at MiTale believe that the future of gaming is in its integration with tasks and needs of everyday life activities that can be personalized and serve each user individually." 15

\section{Business partners}

Over the years, MiTale has created a niche market, with a B2B model of developing solutions for professionals in education, healthcare, and industrial engineering. One of the biggest partners are Coronaria and the University of Turku. MiTale has been collaborating with these partners from the beginning of their existence, by providing their beneficiaries with, for instance, speech therapy tools and gamified solutions. MiTale also collaborates with Indium Technology and BitByByte Creations, on software development projects. Besides, it has the Finnish Speech Therapy Association, as well as Coronaria - Speech Therapy Services as partners. ${ }^{16}$

However, when choosing close business partners, the company is very careful. They prefer long-term relationships with trustful and committed parties. As the CEO of the company argues:

"In our past collaborations with different companies, we saw that having investors who not necessarily know how the gaming industry function, or how gaming market functions, can be a really bad choice. So when MiTale opens an investment round, we are very selective about investors."

The key to success in business partnerships lies in the expertise of the individuals that are in the team. It is all about mutual trust. Especially with SMEs in the gaming industry, network relationships, previous results, and the ability to adapt to the continuously changing market in the gaming field are the main sources of success. As Natasha highlights:

"Because of my own and my team members' well-known reputation, MiTale gets recognition on the market. All of my previous experience and my multiple roles in industry, both in Finland and abroad, are benefiting the corporate brand of the company. Besides that, people want to work with people that I trust."

\footnotetext{
14 Ibid.

${ }^{15}$ https://mitale.fi/ (accessed 25.06.2019)

${ }_{16}$ Halmeenmäki (2019)
} 
Collaborations are often a result of the CEO's personal connections and previous business relationships, or a result of word-of-mouth and recommendations given on the market. These aspects of branding are playing a crucial role in networking:

"Once again, we are not new to our field of work. We have been working with various teams and on various game business strategies before, and that is where the trust has been made. As for acquiring new customers, in most cases, they find us first."

\section{Interactive Network Branding as a solution and a way forward}

After consulting with her business consultant and the team members, Natasha has made a decision to focus her energy on developing a small number of business relationships and on maintaining those partnerships. Each of them will play a great role in further business development of MiTale, as well as their stronger positioning on the market.

By keeping a small number of employees, Natasha can be sure that the corporate identity of MiTale is well developed and understood by every single firm representative. Moreover, when the identity is communicated externally in the right manner, it will result in a positive reputation on the market. By keeping the carefully chosen business partners, MiTale can invest in longterm relationship development, where trust and commitment will develop and keep those companies together, even when hardships come along.

However, the question appears: what will happen with all those new partnerships requests? Well, MiTale will keep getting those, even more in the future than now. Nevertheless, the solution is to outsource part of the tasks or give recommendations and referrals for companies that can help the client in their specific demands. In this way, not only that Natasha can keep MiTale small and efficient, but she can also help other small companies to grow and develop their activities on the market. At certain points, she might even help her competitors, but that is all part of MiTale's business. As Natasha argues:

"So basically, if you had the same type of game you aim for the same target audience, it is better to join the forces and develop a cross-promotional strategy. I do not see the competition on the market whatsoever. I, on the contrary, want to collaborate with other fellow professionals to boost both our businesses in order to get the most out of it."

At the end of a day, collaboration with partners and a goal to develop a better future through gaming will influence their mutual recognition on the market, reputation, as well as strategic positions.

\subsection{Insights for managers}

The Interactive Network Branding process is built around a coherent integration of corporate brand identity and reputation, while being communicated and deployed through human-to- 
human $(\mathrm{H} 2 \mathrm{H})$ interactions between firm representatives. By solely being aware of the influence that $\mathrm{H} 2 \mathrm{H}$ interactions can have on the firm and its branding and networking, can already have a positive influence on the successful implementation of INB.

Many founders of SMEs have created successful companies, by doing 'all the right' steps. However, more frequently than not, they were not aware of their doings. They used their 'gut feeling while relying on the most important business partners. As a result, they have created some strong social connections and even friendships, which helped them grow their business further than they could go alone. This is exactly what we are aiming to describe by INB, this synergy of mutual collaboration and long-term commitment between business partners. If every founder and every employee of an SME would be aware of the benefits INB can bring them, they could use it more efficiently, and create successful enterprises more easily and with less hurdle. In this manner, INB can be implemented even without large sums of money invested in advertising or branding materials. Instead, companies could use that money on developing the connection between employees, while strengthening their products and services, and maintaining close business relationships. Only when the firm is built strong inside, it can have a consistent and valid communication results from the outside.

Some examples of SMEs who grew from scratch, by the devotion of their individual founders are, for instance, Microsoft and Dell Computer. However, it is important to keep in mind that corporate brands can be very easily destroyed, with or without the fault of the firm itself. Sometimes, the reason can be a certain critical event in the firm's business network, sometimes it is the fault of the firm's close partners, or sometimes an innocent mistake done by the employee. No matter what happens, the consequences can be fatal. More about this topic is being discussed in the next chapter (Chapter 14).

\section{Definitions of key terms}

Interactive Network Branding (INB): INB refers to business interactions between SMEs that develop their corporate brands, while firms are acting in their roles and aiming towards the creation of desired network positions.

Human-to-human $(\mathrm{H} 2 \mathrm{H})$ interactions: These interactions represent all the interactions that occur in business network settings, with a goal to exchange information, buy or sell products and services, improve certain aspects of the business relationship, give advice, or connect companies one with another. $\mathrm{H} 2 \mathrm{H}$ interactions are the core processes of Interactive Network Branding.

Boundary spanning interactions: These interactions are the core of INB activities. They present interactions between employees of the company and their potential and current business partners. These interactions, as Koporcic and Halinen (2018, p. 398) describe "occur at the borderline between a company and its network environment." 